\title{
Importance of lateral lagoons for the ichthyofauna in a large tropical reservoir
}

\author{
Ferrareze, M.* and Nogueira, $M G$. \\ Departamento de Zoologia, Instituto de Biociências, Universidade Estadual Paulista - UNESP, \\ CP 510, CEP 18618-000, Botucatu, SP, Brazil \\ *e-mail: mferrareze@ibb.unesp.br
}

Received June 4, 2010 - Accepted February 2, 2011 - Distributed December 31, 2011

(With 8 figures)

\begin{abstract}
This study aimed to analyse the composition and the ecological attributes of small-sized fish assemblages in four lagoons and in the main channel of Rosana Reservoir (SE Brazil). Fieldwork was carried out in September and November/2004 and January, March, May and August/2005. In each sampling station and period five manual throws were performed towards aquatic macrophyte stands, using a hand net $(1.5 \times 5 \mathrm{~m} ; 0.3 \mathrm{~cm}$ of mesh size). The ichthyofauna collected was represented by 42 species, totalizing 3,424 individuals, 2,186 $\mathrm{g}$ in weight. The order Characiformes was dominant, mainly in the lagoons with low connectivity with the river. The main taxon (Importance Index) was Hemigrammus marginatus. Higher richness, abundance, biomass, diversity and lower individual mean length were observed in the lagoons, especially during the rainy period. Spatial segregation of some species was showed by the canonical correspondence analysis indicating the habitat complexity. The results validate the hypotheses that lateral lagoons have a prominent ecological role in the life cycle of juveniles and small fish and demonstrate how the connectivity river/lagoons may be important for assemblages maintenance.
\end{abstract}

Keywords: small fish, juveniles, Rosana Reservoir, Paranapanema River, limnological variables.

\section{Importância das lagoas laterais para a ictiofauna num grande reservatório tropical}

\section{Resumo}

O objetivo deste estudo foi analisar a composição e os atributos ecológicos das assembleias de peixes de pequeno porte em quatro lagoas e no canal principal do reservatório de Rosana, no rio Paranapanema (SE, Brasil). Os trabalhos de campo foram realizados em setembro e novembro de 2004 e janeiro, março, maio e agosto de 2005. Em cada coleta foram realizados cinco arrastos manuais junto aos bancos de macrófitas, utilizando uma rede de arrasto $(1,5 \times 5 \mathrm{~m}$; $0,3 \mathrm{~cm}$ entre nós). Foram coletados 42 espécies e 3.424 indivíduos, totalizando $2.186 \mathrm{~g}$ de biomassa. A ordem Characiformes foi dominante, especialmente nas lagoas com menor conectividade com o rio. O principal táxon (Índice de Importância) foi Hemigrammus marginatus. Altos valores de riqueza, abundância, biomassa, diversidade e menor comprimento médio dos indivíduos foram observados nas lagoas, especialmente durante o período chuvoso. A análise de correspondência canônica mostrou haver segregação entre algumas espécies. Os resultados corroboram as hipóteses de que as lagoas marginais têm um importante papel ecológico no ciclo de vida dos juvenis e das espécies de pequeno porte e demonstra como a conectividade rio/lagoa é importante para a manutenção dessas assembléias.

Palavras-chave: peixes de pequeno porte, reservatório de Rosana, rio Paranapanema, variáveis limnológicas.

\section{Introduction}

The construction of reservoirs has been intensified in developing countries during the last decades (Kennedy et al., 2003). In Brazil, these systems are especially designed to attend increasing demands for energy. Presently, $90 \%$ of the electric consumption is provided by hydropower plants (ca. 70.000 MW) (Tundisi and Matsumura-Tundisi, 2003). As a consequence, the regional riverine systems have been transformed in large and spatially complex lentic (or semi-lentic) ecosystems (Soares et al., 2008), which also influence the downstream stretches (Naliato et al., 2009).
River regulation represents a major impact on fish assemblages and can drastically change the species composition and abundance. Some species cannot survive in the newly-created environment while others can become excessively abundant (Ahearn et al., 2005; Pelicice and Agostinho, 2008).

The filling up of reservoirs can increase the connectivity between river and floodplain habitats, or even take to the formation of artificial lagoons (Henry, 2005). The lateral lagoons might play an important role for 
biodiversity maintenance of the entire fluvial ecosystem (Baumgartner et al., 2004). These environments are highly productive, exhibit numerous microhabitats and are colonised by rich assemblages of plants, invertebrate and vertebrate fauna (Pieczynska, 1995). Therefore, these environments are extremely relevant for conservation of the freshwater fish fauna (De Lima and Araujo-Lima, 2004).

In the Neotropical region, the lateral habitats, especially lagoons and tributary entrances, are considered as natural spawning and growing sites for the ichthyofauna (Meschiatti et al., 2000; Casatti et al. 2003; Pelicice et al., 2005). These environments offer essential resources for the lifecycle strategies and tactics (refuge, reproduction, feeding, growth, etc.) for many fish species (Agostinho et al., 2000).

An important structural component of lateral lagoons is the presence of large stands of aquatic macrophytes. The dominance of small-sized species of the ichthyofauna associated with these plants, as well as juveniles of larger ones, has been well documented in Brazil (Agostinho et al., 2002; Casatti et al., 2003; Pelicice and Agostinho, 2006). The two main factors that explain the high density of small fish in vegetated habitats are the availability of food resources and shelter against predators (Rozas and Odum, 1988; Schriver et al., 1995).

Information on fish fauna for Rosana Reservoir, located in the Paranapanema River (SE Brazil), is restricted (Casatti et al., 2003; Pelicice and Agostinho, 2005, 2006, 2009) and no study has yet focused on the importance of the different kinds of lateral lagoons on these organisms.

For the present study, two hypotheses were formulated. The first is that the lateral lagoons have a prominent ecological role for the ichthyofauna, mainly for small fish. The second one is that the degree of lagoon/river connectivity influences the composition and the ecological attributes of small fish fauna.

Thus, this research aimed to validate the proposed hypothesis through the analysis of the composition and the ecological attributes of small-sized fish assemblages in four lagoons in the main channel of Rosana Reservoir. The specific objectives were to determine the spatial and temporal variation in the composition, richness, abundance and diversity and to correlate the abundance of fish and the limnological variables simultaneously measured (transparency, temperature, $\mathrm{pH}$, electric conductivity of water, turbidity and concentrations of dissolved oxygen, suspended matter and total nutrients).

\section{Material and Methods}

\subsection{Study area}

The study area corresponds to the upstream (tail) zone of Rosana Reservoir, approximately $80 \mathrm{~km}$ above dam (Figure 1 ), which is located at $22^{\circ} 36^{\prime} \mathrm{S}$ e $52^{\circ} 52^{\prime} \mathrm{W}$. The reservoir is the last one from a series of eleven along the Paranapanema River (SP/PR, Brazil), with a surface area of $276 \mathrm{~km}^{2}$ (watershed of $11,000 \mathrm{~km}^{2}$ ), water retention time of 21 days (annual mean values), relatively shallow (maximum of $26 \mathrm{~m}$ close to the dam) and oligo-mesotrophic (Nogueira et al., 2006).

The climate is subtropical humid (average temperature of $21^{\circ} \mathrm{C}$ ) with two pronounced seasons, dry weather predominates from April to August (autumn/winter), and the rains are concentrated in late spring and summer (from November to March) (Duke Energy, 2003). During the study period, the rainy season ranged from September/2004 to January/2005 (monthly average of $157 \mathrm{~mm}$ ), while the dry period ranged from February to August of 2005 (monthly average of $70.7 \mathrm{~mm}$ ). The accumulated rain precipitation in the study year was $1,207.5 \mathrm{~mm}$. The rain precipitation data was provided by the meteorological station of the State Park of Morro do Diabo, municipality of Teodoro Sampaio (State of São Paulo).

\subsection{Data collection}

The study was carried out in 4 lagoons and one sampling station in Paranapanema River (PR), close to the river bank (Figure 1; Table 1). Samplings were carried out in September and November of 2004 and January, March, May and August of 2005.

Two kinds of lagoons were sampled: 3 natural lagoons and one originated by inundation of mining digging (FPA). Two natural lagoons (FPB and FPD) are located inside the State Park of Morro do Diabo while the last one (FPC) is located in an area influenced by human activities (agriculture and cattle breeding). The dominant macrophytes of each lagoon were registered (Table 1). Identification of these plants was performed at the genus level, with help of taxonomists of Botany Department from Biosciences Institute of UNESP/Botucatu.

The sampling stations positioning, the area of each lagoon (integration of geometric distances), as well as their connectivity (transversal section of the lagoon mouth) with the river-reservoir main channel, were determined using a Garmin E-Trex GPS.

Fish were sampled with a net of $7.5 \mathrm{~m}^{2}(1.5 \times 5 \mathrm{~m}$; $0.3 \mathrm{~cm}$ of mesh size). In each point/period five manual throws were performed towards the aquatic macrophyte stands. This sampling system was chosen for its effectiveness for the capture of small fishes. The numerical abundance and biomass in each sampling point and period correspond to an area of $37.5 \mathrm{~m}^{2}$ (integrated area of 5 throws). The organisms were immediately fixed in $10 \%$ formalin.

In the laboratory the organisms were transferred to ethanol $70 \%$ for permanent storage. Voucher specimens are deposited in the Freshwater Fish Collection of the Department of Zoology (FFCZ 2005-21), State University of São Paulo, Campus of Botucatu.

The biometry of all collected organisms was obtained through measurements of weight (biomass in $\mathrm{g}$; Mettler Toledo PB 3002 scale, $0.01 \mathrm{~g}$ accuracy) and standard lenght (paquimeter, $0.1 \mathrm{~mm}$ ) - standard (except for Gymnotiformes and Synbranchiformes) and total.

For taxonomical identification of the fish species, the specialized literature was used (Britski, 1972; Britski et al., 1986; Britski et al., 1999; Reis et al., 2003; Nelson, 


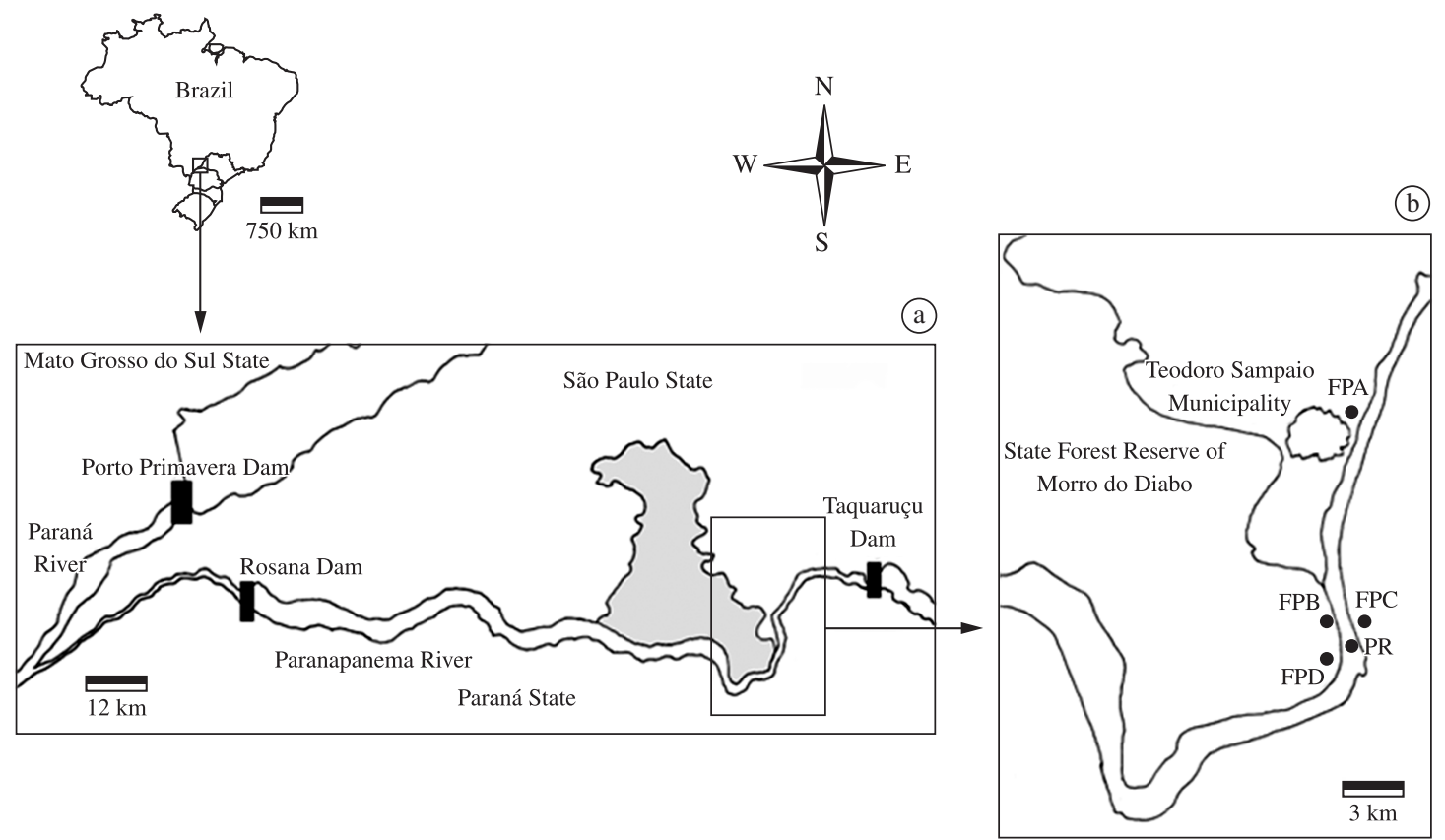

Figure 1. Study area in the region of the confluence of Paraná and Paranapanema Rivers (States of São Paulo - SP, Paraná - PR and Mato Grosso do Sul - MS) showing the positioning of Rosana, Taquaruçu and Porto Primavera dams and the State Park of "Morro do Diabo" (gray area) (a). On the right (detail) the location of the sampling stations and the municipality of Teodoro Sampaio (b).

Table 1. Denomination of the sampling stations, geographical positioning, lagoons surface area, main aquatic macrophytes and estimated area of connectivity of lagoons with the river/reservoir main channel.

\begin{tabular}{|c|c|c|c|c|}
\hline Sampling station & $\begin{array}{l}\text { Geographical } \\
\text { coordinates }\end{array}$ & $\begin{array}{r}\text { Area } \\
\left(\mathbf{k m}^{2}\right)\end{array}$ & Dominant macrophytes & $\begin{array}{c}\text { Connectivity } \\
\left(\mathbf{m}^{2}\right)\end{array}$ \\
\hline $\begin{array}{l}\text { Lateral lagoon A } \\
\text { (FPA) }\end{array}$ & $\begin{array}{l}22^{\circ} 34^{\prime} 03.3 " \mathrm{~S} \text { and } \\
52^{\circ} 09^{\prime} 11.4^{\prime \prime} \mathrm{W}\end{array}$ & 0.110 & $\begin{array}{l}\text { Tipha, Eichhornia, Brachiaria, } \\
\text { Pontederia and Salvinia }\end{array}$ & 50 \\
\hline $\begin{array}{l}\text { Lateral lagoon B } \\
\text { (FPB) }\end{array}$ & $\begin{array}{l}22^{\circ} 36^{\prime} 56.5^{\prime \prime} \mathrm{S} \text { and } \\
52^{\circ} 09^{\prime} 47.3 " \mathrm{~W}\end{array}$ & 0.024 & $\begin{array}{l}\text { Eichhornia, Brachiaria, Pontederia, } \\
\text { Salvinia, Pistia, Egeria and Nymphaea }\end{array}$ & 6.5 \\
\hline $\begin{array}{l}\text { Lateral lagoon } \mathrm{C} \\
(\mathrm{FPC})\end{array}$ & $\begin{array}{l}22^{\circ} 37^{\prime} 28,9 " \mathrm{~S} \text { and } \\
52^{\circ} 09^{\prime} 21.1 " \mathrm{~W}\end{array}$ & 0.721 & $\begin{array}{c}\text { Eichhornia, Brachiaria, Pontederia, } \\
\text { Salvinia and Egeria }\end{array}$ & 525 \\
\hline $\begin{array}{l}\text { Paranapanema } \\
\text { River Bank (PR) }\end{array}$ & $\begin{array}{l}22^{\circ} 37^{\prime} 51.6 " \mathrm{~S} \text { and } \\
52^{\circ} 09^{\prime} 30.5 " \mathrm{~W}\end{array}$ & - & $\begin{array}{l}\text { Tipha, Eichhornia, Brachiaria, } \\
\text { Pontederia, Salvinia and Pistia }\end{array}$ & - \\
\hline $\begin{array}{l}\text { Lateral lagoon D } \\
(\mathrm{FPD})\end{array}$ & $\begin{array}{l}22^{\circ} 38^{\prime} 22.0 ” \mathrm{~S} \text { and } \\
52^{\circ} 09^{\prime} 29.0 ” \mathrm{~W}\end{array}$ & 0.063 & $\begin{array}{l}\text { Eichhornia, Brachiaria, Pontederia, } \\
\text { Salvinia, Pistia and Nymphaea }\end{array}$ & 60.2 \\
\hline
\end{tabular}

2006; Graça and Pavanelli, 2007) and consultations of the scientific collections of the State University of São Paulo (Campus S. J. R. Preto) and University of São Paulo Museum (MZUSP) were made.

The limnological variables were measured in order to characterise the sampling points. Temperature, dissolved oxygen, $\mathrm{pH}$ and conductivity were measured at every $0.5 \mathrm{~m}$, using a multiprobe water analyser Horiba (U-22); water transparency, with a Secchi disk and turbidity, measured with a turbidimeter MSTecnopon. Sub surface (ca. $1.0 \mathrm{~m}$ ) water samples were collected (Van Dorn bottle) for determination of the total nitrogen (Mackreth et al., 1978), total phosphorus (Strickland and Parsons, 1960), after physical and chemical digestion (Valderrama, 1981), and suspended solids by gravimetry (Cole, 1979).

\subsection{Data analyses}

Numerical richness, abundance and biomass were calculated for the communities while Index of Importance (Nataragam and Jhingian, 1961 apud Beaumord and Petrere, 1994) was calculated for each species. In terms of frequency (\%) of capture (c) the species were classified as constants $(\mathrm{C}>50 \%)$, accessory $(25<\mathrm{A}<50 \%)$ and rare $(\mathrm{R}<25 \%)$ (Dajoz, 1973).

The Shannon-Wiener index, which is widely used in analyses of communities structure (Magurran, 2004), was 
calculated to estimate the fish assemblage diversity of each lagoon in the distinct sampling periods.

The mean values of the community attributes were calculated to synthesise the information and facilitate the identification of patterns. Two periods were considered in the analysis: rainy and dry periods. The representativeness of the means was assumed based on the normal data distribution (Shapiro-Wilk's W test) (Underwood, 1997; Statsoft, 2001).

A one-way ANOVA test was performed to detect differences among sampling sites. When differences were detected, the Tukey test was applied to determine the level of significance (Underwood, 1997). Differences between the periods were tested by the test $t$-Student, using the mean of the variables for each season (dry and rainy). Values of $\mathrm{p}<0.05$ (Underwood, 1997) were considered statistically different. The analyses were performed using StatisticaTM 6.0 software (Statsoft, 2001).

A cluster analysis was performed (NtSys), using the accumulated numerical abundance of the species in each sampling point, for identification of the degree of similarity among the studied sites. For this grouping analysis, the index of Morisita-Horn was applied. It is widely used in community ecology because is less influenced by species which were not collected (zeros) (Krebs, 1989).

A canonical correspondence analysis, CCA (Pcordwin) (McCune and Mefford, 1999) was used to verify correlations between the fish species and the limnological variables, per sampling site and period. The data were previously standardised $\left(\log _{\mathrm{x}+1}\right)$, except for $\mathrm{pH}$, for the diminution of intrinsic data variability and to enhance the degree of the analysis explicability.

Finally, a correlation analysis (r-Pearson) (Sokal and Rohlf, 1979) between the lagoon connectivity and the fish abundance was carried out, in order to evaluate whether the connectivity lagoon/river influences the composition and the ecological attributes of small fish. For this analysis, the temporal series of data obtained along the six samplings for each lagoon was used. The representativeness of the data was assumed based on the normal data distribution (Shapiro-Wilk's W test) (Underwood, 1997; Statsoft, 2001).

\section{Results}

\subsection{Ichthyofauna}

A total of 3,424 individuals, from 42 species, was collected during the study (Table 2). The order Characiformes was the most abundant, totalising $95.4 \%$ of the individuals, followed by Perciformes, $2.5 \%$, and Siluriformes, $1.2 \%$. Other orders represented only $0.9 \%$ of the individuals.

Higher richness was observed in the lagoons and lower in the river central channel (Figure 2). Temporally, richness was higher in the rainy period (12 species) compared to the dry period $(7$ species $)(\mathrm{p}<0.001)$.

The fish abundance was significantly higher at the lagoon FPA $(p<0.01)$ (Figure 3$)$. The other sampling stations exhibited a similar mean value (ca. 100 individuals; $p=0.837)$. Higher numbers of individuals were collected in the rainy period (156 individuals) compared to the dry period (72 individuals) $(\mathrm{p}=0.03)$.

Higher values of biomass (Figure 4) were found at the FPD station, followed by FPA $(p=0.048)$. The other three sampling stations (FPB, FPC and PR) exhibited a similar biomass $(\mathrm{p}>0.05)$. The rainy period exhibited a higher biomass ( $89 \mathrm{~g}$ ) compared to the dry period (56 g) $(\mathrm{p}<0.01)$.

Higher individual mean length was observed at the river sampling station, PR (37 mm), followed by the most connected lagoon, FPC (34 mm). Lower individual mean length was observed during the rainy period, $26 \mathrm{~mm}$, and higher in the dry period, $44 \mathrm{~mm}(\mathrm{p}=0.042)$.

The numerical abundance, biomass and mean length of each species are also shown in Table 2.

Data of relative abundance, considering all periods for each sampling site (Figure 5), showed that Characiformes was more abundant in the lagoons, while Perciformes, Siluriformes and Gymnotiformes were more important in the river channel.

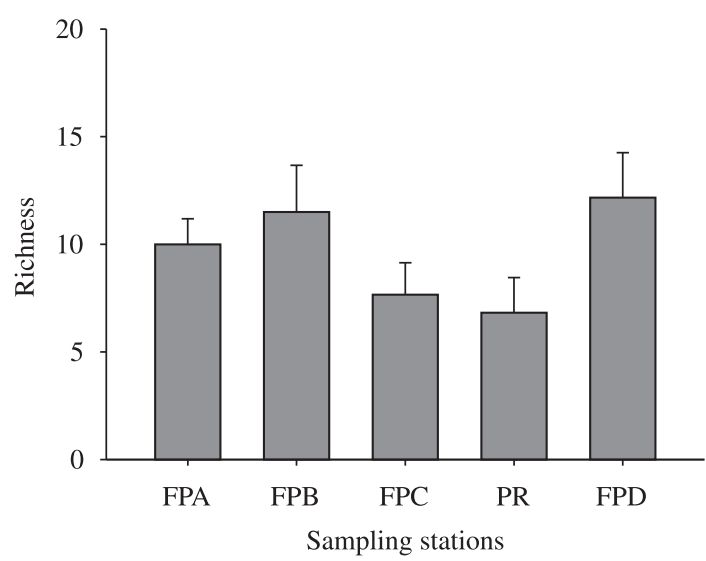

Figure 2. Mean value (and standard deviation) of species richness at the different sampling stations.

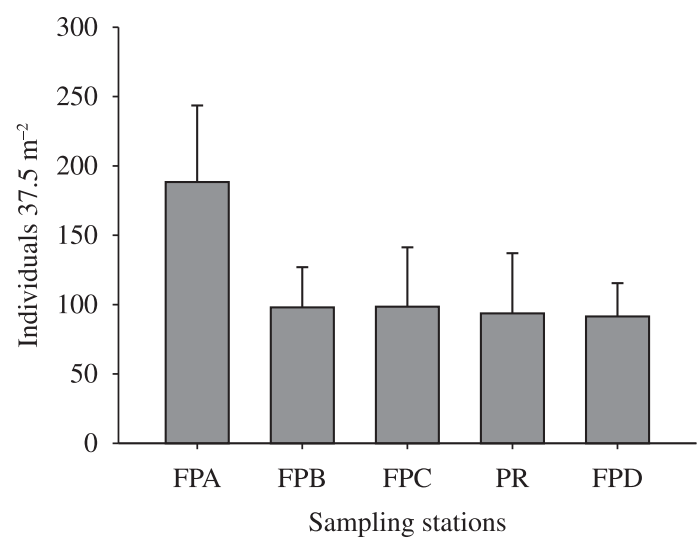

Figure 3. Mean value (and standard deviation) of absolute abundance of the ichthyofauna (individuals per $37.5 \mathrm{~m}^{2}$ of net) (sampling effort) at the sampling stations, considering the different study periods. 
Table 2. List of taxa identified during the study, abbreviation used for the statistical analyses, absolute (n) and relative (n\%) abundance, mean length (L) in $\mathrm{mm}$, and total biomass (Wt; g).

\begin{tabular}{|c|c|c|c|c|c|}
\hline Taxon & Family & Abbreviation & $\mathbf{n}$ & $\mathbf{L}$ & Wt (g) \\
\hline \multicolumn{6}{|l|}{ Order Characiformes } \\
\hline Astyanax altiparanae Garutti \& Britski, 2000 & Characidae & sp1 & 82 & 25 & 83.6 \\
\hline Acestrorhynchus lacustris (Lütken, 1875) & Acestrorhynchidae & $\mathrm{sp} 2$ & 3 & 16 & 10.5 \\
\hline Apareiodon piracicabae (Eigenmann, 1907) & Parodontidae & $\mathrm{sp} 3$ & 10 & 21 & 16.7 \\
\hline Aphyocharax anisitsi Eigenmann \& Kennedy, 1903 & Characidae & sp4 & 169 & 18 & 87.2 \\
\hline Bryconamericus stramineus Eigenmann, 1908 & Characidae & sp5 & 330 & 23 & 202.1 \\
\hline Cyphocharax modestus (Fernández-Yépez, 1948) & Curimatidae & sp6 & 35 & 20 & 15.4 \\
\hline Galeocharax knerii (Steindachner, 1875) & Characidae & sp7 & 1 & 31 & 1.1 \\
\hline Hemigrammus marginatus Ellis, 1911 & Characidae & $\operatorname{sp} 8$ & 1288 & 18 & 547.8 \\
\hline Hoplias malabaricus (Bloch, 1794) & Erythrinidae & sp9 & 4 & 74 & 36 \\
\hline Hyphessobrycon eques (Steindachner, 1882) & Characidae & sp10 & 677 & 17 & 271.5 \\
\hline Leporinus friderici (Bloch, 1794) & Anostomidae & sp11 & 3 & 32 & 5.8 \\
\hline Leporinus octofasciatus Steindachner, 1915 & Anostomidae & sp12 & 2 & 20 & 0.6 \\
\hline Leporinus striatus Kner, 1858 & Anostomidae & sp13 & 1 & 30 & 1.5 \\
\hline Metynnis lippincottianus (Cope, 1870) & Characidae & sp14 & 2 & 14 & 0.3 \\
\hline Moenkhausia intermedia Eigenmann, 1908 & Characidae & sp15 & 34 & 16 & 34.3 \\
\hline Myleus tiete (Eigenmann \& Norris, 1900) & Characidae & sp16 & 2 & 16 & 1.5 \\
\hline Oligosarcus pintoi Amaral Campos, 1945 & Characidae & sp17 & 15 & 22 & 9.6 \\
\hline Roeboides descalvadensis Fowler, 1932 & Characidae & sp18 & 109 & 28 & 70.5 \\
\hline Schizodon nasutus Kner, 1858 & Anostomidae & sp19 & 6 & 28 & 3.7 \\
\hline Serrapinnus notomelas (Eigenmann, 1915) & Characidae & sp20 & 312 & 19 & 251 \\
\hline Serrasalmus maculatus Kner, 1858 & Characidae & $\operatorname{sp} 21$ & 112 & 16 & 55.9 \\
\hline Serrasalmus marginatus Valenciennes, 1836 & Characidae & $\mathrm{sp} 22$ & 1 & 22 & 2.1 \\
\hline $\begin{array}{l}\text { Steindachnerina brevipinna } \\
\text { (Eigenmann \& Eigenmann, 1889) }\end{array}$ & Curimatidae & $\mathrm{sp} 23$ & 67 & 30 & 119 \\
\hline \multicolumn{6}{|l|}{ Order Gymnotiformes } \\
\hline Eigenmannia trilineata López \& Castello, 1966 & Sternopygidae & $\mathrm{sp} 24$ & 5 & 47 & 16.3 \\
\hline Eigenmannia virescens (Valenciennes, 1842) & Sternopygidae & $\mathrm{sp} 25$ & 2 & 100 & 3.9 \\
\hline Gymnotus carapo Linnaeus, 1758 & Gymnotidae & sp26 & 21 & 47 & 49.6 \\
\hline Rhamphichthys hahni (Meinken, 1937) & Rhamphichthyidae & sp27 & 1 & 28 & 0.1 \\
\hline \multicolumn{6}{|l|}{ Order Siluriformes } \\
\hline Hypostomus ancistroides (Ihering, 1911) & Loricariidae & sp28 & 22 & 19 & 13.3 \\
\hline Hypostomus sp1 & Loricariidae & sp29 & 12 & 15 & 10.1 \\
\hline Hypostomus sp2 & Loricariidae & sp30 & 1 & 28 & 0.5 \\
\hline $\begin{array}{l}\text { Loricariichthys platymetopon } \\
\text { Isbrücker \& Nijssen, } 1979\end{array}$ & Loricariidae & $\operatorname{sp} 31$ & 2 & 24 & 0.2 \\
\hline Trachelyopterus galeatus (Linnaeus, 1766) & Auchenipteridae & $\operatorname{sp} 32$ & 1 & 61 & 11 \\
\hline Pimelodus maculatus Lacepède, 1803 & Pimelodidae & sp33 & 1 & 28 & 0.5 \\
\hline Rhamdia quelen (Quoy \& Gaimard, 1824) & Heptapteridae & sp34 & 1 & 38 & 2 \\
\hline \multicolumn{6}{|l|}{ Order Perciformes } \\
\hline Cichla kelberi Spix \& Agassiz, 1831 & Cichlidae & sp35 & 18 & 32 & 28.2 \\
\hline Cichlasoma paranaense Kullander, 1983 & Cichlidae & sp36 & 13 & 29 & 77.3 \\
\hline Crenicichla britskii Kullander, 1982 & Cichlidae & sp37 & 35 & 25 & 122.6 \\
\hline Crenicichla haroldoi Luengo \& Britski, 1974 & Cichlidae & sp38 & 2 & 19 & 0.4 \\
\hline Crenicichla niederleinii (Holmberg, 1891) & Cichlidae & sp39 & 3 & 28 & 2.8 \\
\hline Satanoperca pappaterra $($ Heckel, 1840) & Cichlidae & sp40 & 15 & 17 & 14.5 \\
\hline \multicolumn{6}{|l|}{ Order Synbranchiformes } \\
\hline Synbranchus marmoratus Bloch, 1795 & Synbranchidae & sp41 & 2 & 130 & 5.1 \\
\hline \multicolumn{6}{|l|}{ Order Rajiformes } \\
\hline Potamotrygon motoro (Müller \& Henle, 1841) & Potamotrygonidae & $\mathrm{sp} 42$ & 2 & $*$ & $*$ \\
\hline
\end{tabular}

*Missing data. 
In terms of Species Importance (I) the main species was Hemigrammus marginatus, for all sampling stations (Table 3). Other abundant species were Hyphessobrycon eques, Bryconamericus stramineus and Serrapinus notomelas for Characiformes; Crenicichla britskii for Perciformes; Hypostomus ancistroides for Siluriformes and Gymnotus carapo for Gymnotiformes.

The species H. marginatus, H. eques, Aphyocharax anisitsi and $C$. britskii were classified as constant at all sampling stations (Table 3). There was a homogeneous distribution among rare, accessory and constant species in the river. The maximum occurrence of rare species $(52 \%)$ was seen at FPC and the most constant ones at FPA, FPB and FPD.

The variation of the Shannon-Wiener ( $\left.\mathrm{H}^{\prime}\right)$ diversity was higher in the lagoons when compared to the river channel and the highest value was calculated for FPD (Figure 6). In general the diversity was higher in the

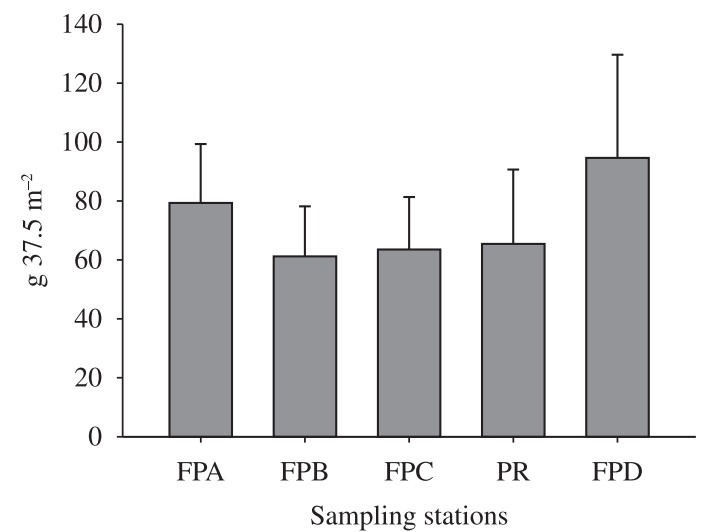

Figure 4. Mean value (and standard deviation) of biomass of the ichthyofauna (grams per $37.5 \mathrm{~m}^{2}$ of net, sampling effort) at the sampling stations, considering the different study periods.

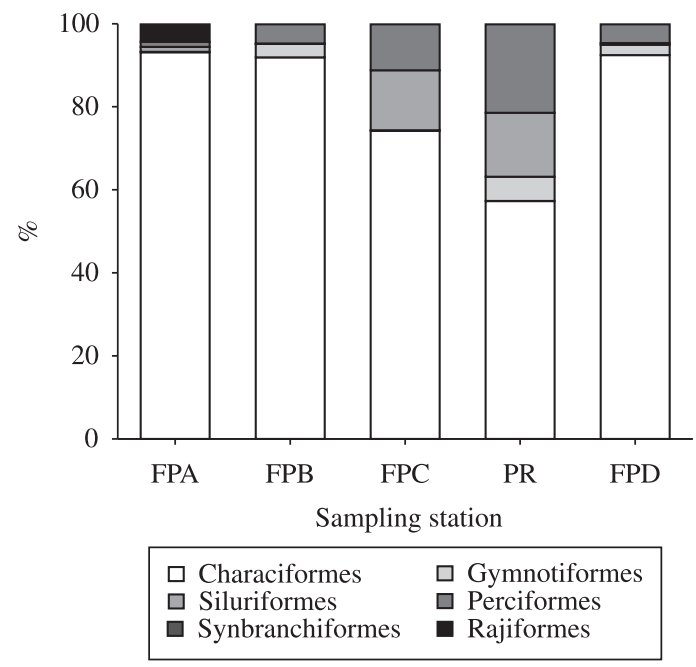

Figure 5. Relative abundance of the ichthyofauna, per Order, at the different sampling stations, considering the different study periods. rainy period ( 2.4 bits.org $\left.^{-1}\right)$ and lower in the dry period $\left(1.8\right.$ bits.org $\left.{ }^{-1}\right)(\mathrm{p}=0.047)$.

Differences among the sampling stations, based on the fish composition and abundance, were evidenced by the similarity analyses (Figure 7). The lagoons FPA, FPB and FPD had a more similar and abundant ichthyofauna, while the river assemblage (PR) was associated with the lagoon FPC. The ichthyofauna was more similar between FPA and FPB. In these lagoons, a high number of $H$. eques and the low occurrence of $R$. descalvadensis and $S$. maculatus were observed, as well as the exclusive presence of Leporinus octofasciatus. The graphical superior positioning of the FPA in the similarity analysis is related to the highest absolute abundance (1,130 individuals) and the exclusive occurrence of Rhamphichthys hahni and Potamotrygon motoro. This station also had a high presence of $H$. marginatus, H. eques, S. notomelas and C. kelberi and no capture of Oligosarcus pintoi. The segregation of FPC

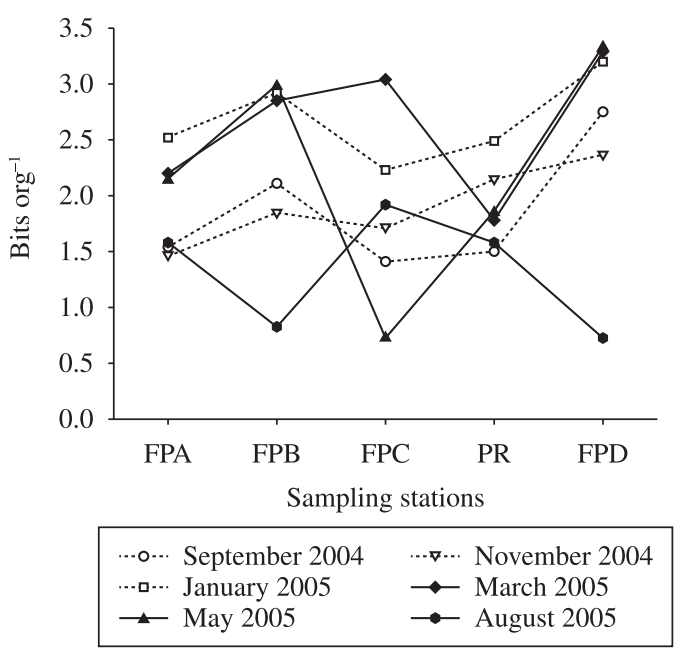

Figure 6. Shannon-Wiener diversity index ( $\left.\mathrm{H}^{\prime}\right)$ of the ichthyofauna at the sampling stations, during the different study periods.

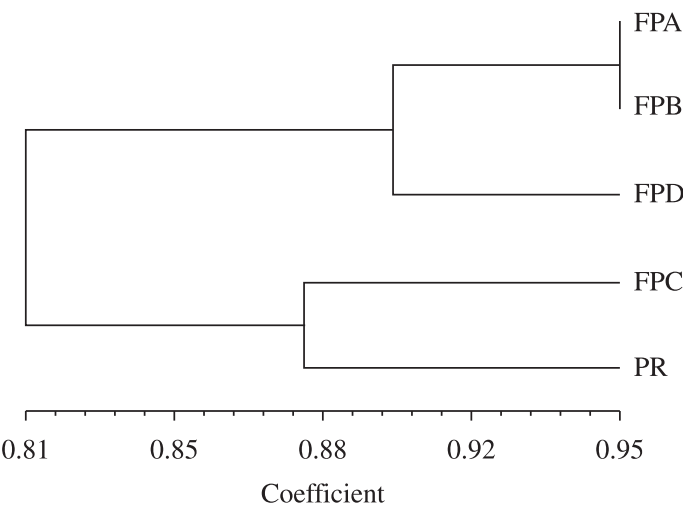

Figure 7. Similarity analysis on the basis of the ichthyofauna composition and abundance at the sampling stations. 
Table 3. Index of importance of the species (I; \%) (in bold, the 5 most important species in each sampling point) and the capture constancy classification $(\mathrm{c})$, where $\mathrm{C}=$ constant, $\mathrm{A}=$ accessory and $\mathrm{R}=$ rare.

\begin{tabular}{|c|c|c|c|c|c|c|c|c|c|c|c|c|c|c|c|}
\hline \multirow{2}{*}{$\begin{array}{l}\text { Taxon } \\
\text { Order } \\
\end{array}$} & \multicolumn{3}{|c|}{ FPA } & \multicolumn{3}{|c|}{ FPB } & \multicolumn{3}{|c|}{ FPC } & \multicolumn{3}{|c|}{ PR } & \multicolumn{3}{|c|}{ FPD } \\
\hline & I & c & & I & c & & I & c & & I & c & & I & c & \\
\hline \multicolumn{16}{|l|}{ Characiformes } \\
\hline A. altiparanae & 0 & 33 & A & 1.17 & 33 & A & 0.67 & 50 & $\mathrm{C}$ & 0.52 & 33 & A & 3.16 & 50 & $\mathrm{C}$ \\
\hline A. acustris & 0 & 0 & & 0 & 0 & & 0 & 0 & & 0.01 & 17 & $\mathrm{R}$ & 0.03 & 17 & $\mathrm{R}$ \\
\hline A. piracicabae & 0 & 17 & $\mathrm{R}$ & 0.06 & 33 & A & 0 & 0 & & 0.01 & 33 & A & 0.03 & 17 & $\mathrm{R}$ \\
\hline A. anisitsi & 0.27 & 67 & $\mathrm{C}$ & 0.1 & 67 & $\mathrm{C}$ & 19.31 & 67 & $\mathrm{C}$ & 0.11 & 50 & $\mathrm{C}$ & 0.37 & 83 & $\mathrm{C}$ \\
\hline B. stramineus & 0.34 & 17 & $\mathrm{R}$ & 5.94 & 33 & A & 21.41 & 33 & A & 14.26 & 33 & A & 4.06 & 17 & $\mathrm{R}$ \\
\hline C. modestus & 0 & 33 & A & 0.01 & 33 & A & 0.05 & 17 & $\mathrm{R}$ & 0.24 & 17 & $\mathrm{R}$ & 0.1 & 17 & $\mathrm{R}$ \\
\hline G. knerii & 0 & 0 & & 0 & 17 & $\mathrm{R}$ & 0 & 0 & & 0 & 0 & & 0 & 0 & \\
\hline H. marginatus & 64.17 & 100 & $\mathrm{C}$ & 55.32 & 100 & $\mathrm{C}$ & 50.87 & 50 & $\mathrm{C}$ & 72.66 & 67 & $\mathrm{C}$ & 37.38 & 100 & $\mathrm{C}$ \\
\hline H. malabaricus & 0 & 0 & & 0.02 & 17 & $\mathrm{R}$ & 0.05 & 17 & $\mathrm{R}$ & 0 & 0 & & 0.06 & 17 & $\mathrm{R}$ \\
\hline H. eques & 30.52 & 100 & $\mathrm{C}$ & 28.42 & 100 & $\mathrm{C}$ & 2.64 & 67 & $\mathrm{C}$ & 1.35 & 50 & $\mathrm{C}$ & 19.32 & 100 & $\mathrm{C}$ \\
\hline L. friderici & 0 & 0 & & 0.02 & 33 & A & 0.01 & 17 & $\mathrm{R}$ & 0 & 0 & & 0 & 0 & \\
\hline L. octofasciatus & 0 & $\mathrm{t} 17$ & $\mathrm{R}$ & 0 & 17 & $\mathrm{R}$ & 0 & 0 & & 0 & 0 & & 0 & 0 & \\
\hline L. striatus & 0 & 0 & & 0 & 0 & & 0 & 17 & $\mathrm{R}$ & 0 & 0 & & 0 & 0 & \\
\hline M. lippincottianus & 0 & 17 & $\mathrm{R}$ & 0 & 0 & & 0 & 0 & & 0 & 0 & & 0 & 17 & $\mathrm{R}$ \\
\hline M. intermedia & 0.09 & 50 & $\mathrm{C}$ & 0.04 & 17 & $\mathrm{R}$ & 0 & 0 & & 0 & 0 & & 1.19 & 33 & A \\
\hline M. tiete & 0 & 0 & & 0 & 17 & $\mathrm{R}$ & 0 & 0 & & 0 & 17 & $\mathrm{R}$ & 0 & 0 & \\
\hline O. pintoi & 0 & 0 & & 0.05 & 33 & A & 0.02 & 17 & $\mathrm{R}$ & 0.01 & 17 & $\mathrm{R}$ & 0.04 & 50 & $\mathrm{C}$ \\
\hline R. descalvadensis & 0.02 & 33 & A & 0.41 & 67 & $\mathrm{C}$ & 2.83 & 33 & A & 1.55 & 33 & A & 0.54 & 67 & $\mathrm{C}$ \\
\hline S. nasutus & 0 & 33 & A & 0 & 17 & $\mathrm{R}$ & 0 & 0 & & 0 & 0 & & 0.02 & 33 & A \\
\hline S. notomelas & 4.33 & 100 & $\mathrm{C}$ & 2 & 67 & $\mathrm{C}$ & 0.62 & 33 & A & 7.28 & 50 & $\mathrm{C}$ & 22.29 & 83 & $\mathrm{C}$ \\
\hline S. maculatus & 0.06 & 67 & $\mathrm{C}$ & 0.33 & 50 & $\mathrm{C}$ & 0.67 & 33 & A & 0.78 & 17 & $\mathrm{R}$ & 2.5 & 83 & $\mathrm{C}$ \\
\hline S. marginatus & 0 & 0 & & 0.01 & 17 & A & 0 & 0 & & 0 & 0 & & 0 & 0 & \\
\hline S. brevipinna & 0.03 & 50 & $\mathrm{C}$ & 3.58 & 50 & $\mathrm{C}$ & 0.04 & 33 & A & 0 & 0 & & 7.35 & 83 & $\mathrm{C}$ \\
\hline \multicolumn{16}{|l|}{ Gymnotiformes } \\
\hline E. trilineata & 0 & 17 & $\mathrm{R}$ & 0.04 & 33 & A & 0.01 & 17 & $\mathrm{R}$ & 0 & 0 & & 0.02 & 17 & $\mathrm{R}$ \\
\hline E. virescens & 0 & 0 & & 0.03 & 33 & A & 0 & 0 & & 0 & 0 & & 0 & 0 & \\
\hline G. carapo & 0 & 0 & & 0.83 & 67 & $\mathrm{C}$ & 0 & 0 & & 0.03 & 33 & A & 0.54 & 67 & $\mathrm{C}$ \\
\hline R. hahni & 0 & 17 & $\mathrm{R}$ & 0 & 0 & & 0 & 0 & & 0 & 0 & & 0 & 0 & \\
\hline \multicolumn{16}{|l|}{ Siluriformes } \\
\hline H. ancistroides & 0.02 & 50 & $\mathrm{C}$ & 0 & 0 & & 0.13 & 67 & $\mathrm{C}$ & 0.06 & 50 & $\mathrm{C}$ & 0 & 0 & \\
\hline Hypostomus sp1 & 0 & 17 & $\mathrm{R}$ & 0 & 17 & $\mathrm{R}$ & 0.09 & 33 & A & 0.01 & 17 & $\mathrm{R}$ & 0 & 0 & \\
\hline Hуроstomus sp2 & 0 & 0 & & 0 & 0 & & 0 & 17 & $\mathrm{R}$ & 0 & 0 & & 0 & 0 & \\
\hline L. platymetopon & 0 & 0 & & 0 & 0 & & 0 & 17 & $\mathrm{R}$ & 0 & 0 & & 0 & 17 & $\mathrm{R}$ \\
\hline T. galeatus & 0 & 0 & & 0 & 0 & & 0.03 & 17 & $\mathrm{R}$ & 0 & 0 & & 0 & 0 & \\
\hline P. maculatus & 0 & 0 & & 0 & 0 & & 0 & 0 & & 0 & 0 & & 0 & 17 & $\mathrm{R}$ \\
\hline R. quelen & 0 & 0 & & 0 & 0 & & 0 & 0 & & 0 & 17 & $\mathrm{R}$ & 0 & 0 & \\
\hline \multicolumn{16}{|l|}{ Perciformes } \\
\hline C. kelberi & 0.05 & 33 & A & 0.05 & 33 & A & 0.02 & 17 & $\mathrm{R}$ & 0 & 0 & & 0.19 & 50 & $\mathrm{C}$ \\
\hline C. paranaense & 0.03 & 33 & A & 0.48 & 50 & $\mathrm{C}$ & 0 & 0 & & 0 & 0 & & 0.58 & 50 & $\mathrm{C}$ \\
\hline C. britskii & 0.05 & 50 & $\mathrm{C}$ & 1.07 & 83 & $\mathrm{C}$ & 0.49 & 50 & $\mathrm{C}$ & 0.96 & 83 & $\mathrm{C}$ & 0.14 & 50 & $\mathrm{C}$ \\
\hline C. haroldoi & 0 & 0 & & 0 & 0 & & 0 & 17 & $\mathrm{R}$ & 0 & 0 & & 0 & 0 & \\
\hline C. niederleinii & 0 & 0 & & 0 & 0 & & 0.01 & 17 & $\mathrm{R}$ & 0 & 0 & & 0 & 17 & $\mathrm{R}$ \\
\hline $\begin{array}{l}\text { S. pappaterra } \\
\text { Synbranchiformes }\end{array}$ & 0 & 0 & & 0 & 0 & & 0 & 17 & $\mathrm{R}$ & 0.14 & 50 & $\mathrm{C}$ & 0.08 & 50 & $\mathrm{C}$ \\
\hline $\begin{array}{l}\text { S. marmoratus } \\
\text { Rajiformes }\end{array}$ & 0 & 0 & & 0.01 & 17 & $\mathrm{R}$ & 0 & 0 & & 0 & 0 & & 0.01 & 17 & $\mathrm{R}$ \\
\hline P. motoro & 0 & 17 & $\mathrm{R}$ & 0 & 0 & & 0 & 0 & & 0 & 0 & & 0 & 0 & \\
\hline
\end{tabular}


from the other lateral lagoons in the similarity analysis and its proximity with the river bank (station PR) is due to a relatively higher capture of $B$. stramineus, $R$. descalvadensis and $H$. ancistroides, compared with the other sampling stations. In these locations, the exclusive occurrence of H. eques and C. kelberi, and the absence of Moenkhausia intermedia, Schizodon nasutus and C. paranaense were also observed. The river bank (PR) showed the most different assemblages with low richness and absence of Cichla kelberi. In this station, a high number of individuals of Myleus tiete and C. britskii were observed, besides the exclusive occurrence of Ramdhia quelen.

The correlation between the ichthyofauna abundance and the lagoons/river connectivity showed that the narrower the connection between the environments, the higher is fish abundance $(r=0.68 ; p=0.003)$. Seasonally, there was no statistical difference among the values of connectivity $(\mathrm{p}=0.721)$.

\subsection{Environmental variables}

The measured limnological variables are shown in Table 4. The main differences were observed at the temporal scale, especially for turbidity, suspended matter and transparency. In August, the dry period, all sampling stations exhibited total transparency of the water. There was also a remarkable increment in the concentration of total suspended solids and nutrients during the rainy period. Among the sampling stations some important differences in the variables between the lagoons and the river were observed. In terms of mean values this last sampling station (PR) exhibited the highest conductivity, suspended solids, turbidity and total phosphorus and the lowest transparency.

\subsection{Canonical correspondence analysis}

The results of the CCA (Figure 8 and Table 5) explained $60.7 \%$ of the data variability $(\mathrm{p}=0.01)$, considering the three first ordination axes (axis $1=29.6 \%$, axis $2=26.2 \%$ and axis $3=4.9 \%$ ). The species A. anisitsi (sp4), Leporinus

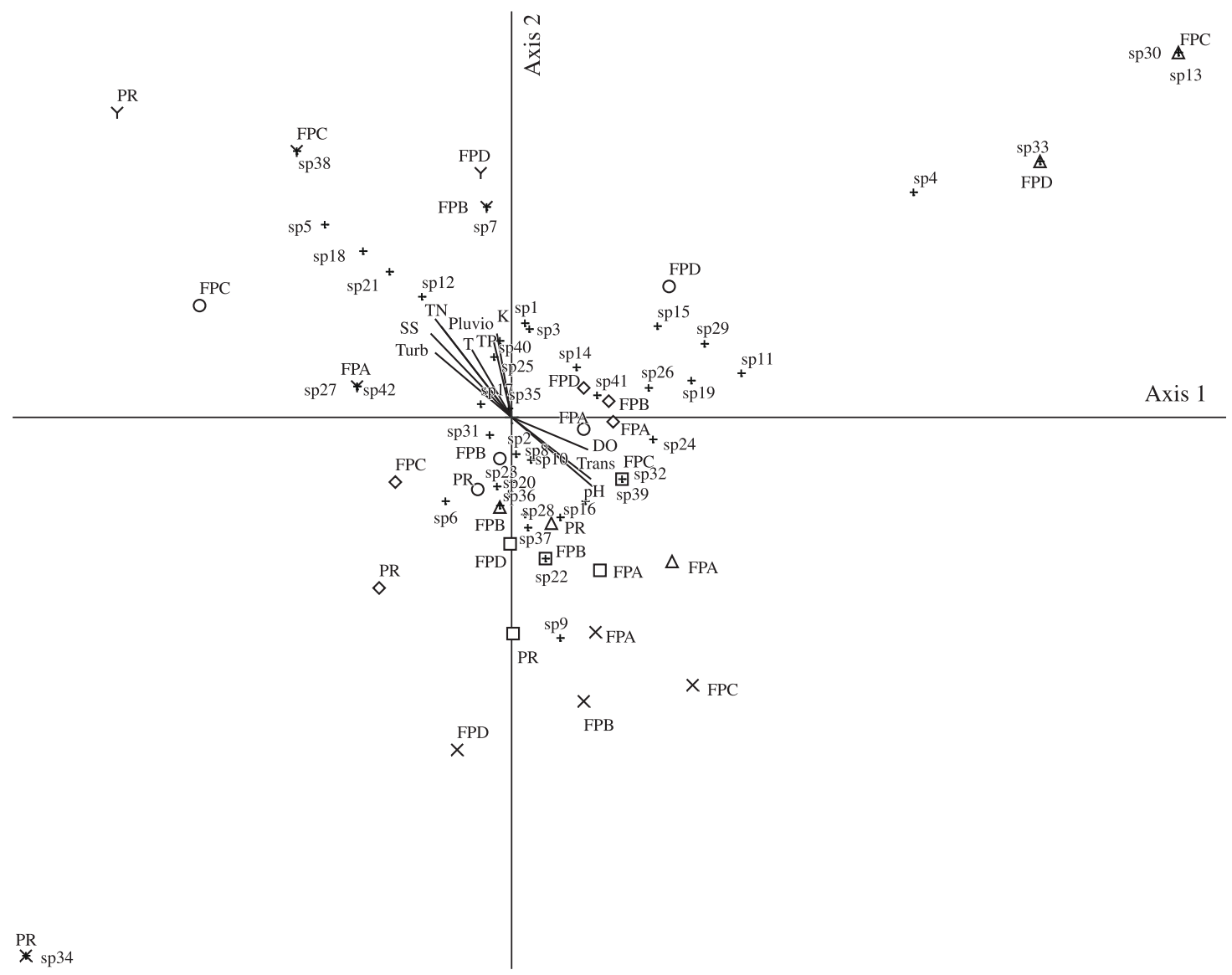

Months

$\times$ September $2004 \diamond$ November $2004 \quad$ Y January $2005 \square$ March $2005 \Delta$ May 2005 ○ August 2005

Figure 8. Canonical correspondence analysis (CCA) showing the distribution of the ichthyofauna species in relation to the limnological variables. See Table 2 and 5 for abbreviations. 


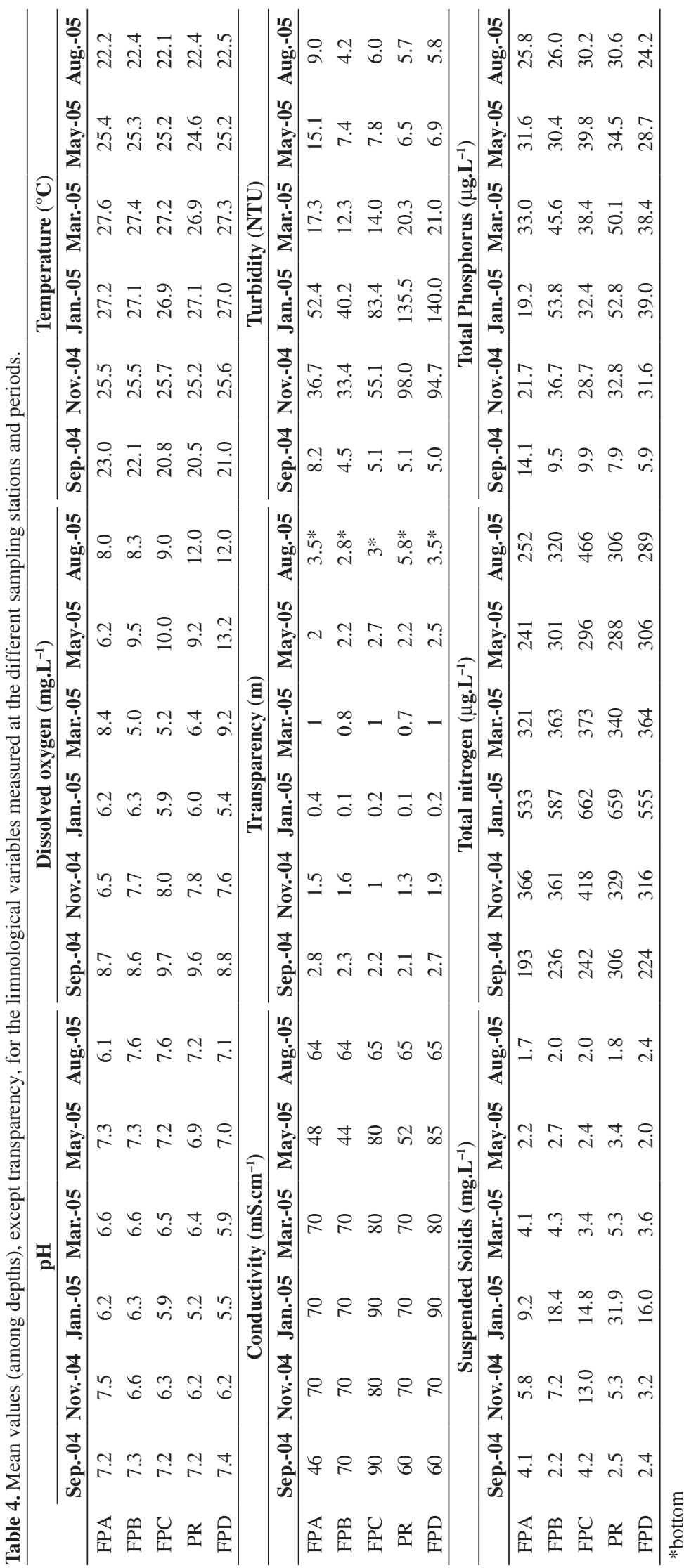


Table 5. Significant $(r>0.4)$ correlations of the biotic and abiotic variables with the main components 1 e 2 (CCA analysis).

\begin{tabular}{lccc}
\hline & Abbreviation & r (Axis 1) & r (Axis 2) \\
\hline Biotic & & & 0.376 \\
A. anisitsi & $\mathrm{sp} 4$ & 0.515 & 0.531 \\
B. stramineus & $\mathrm{sp} 5$ & -0.437 & 0.365 \\
L. striatus & $\mathrm{sp} 13$ & 0.547 & 0.492 \\
R. descalvadensis & $\mathrm{sp} 18$ & -0.312 & 0.526 \\
S. maculatus & $\mathrm{sp} 21$ & -0.371 & 0.365 \\
Hypostomus sp2 & $\mathrm{sp30}$ & 0.547 & 0.265 \\
P. maculatus & $\mathrm{sp33}$ & 0.481 & -0.498 \\
R. quelen & $\mathrm{sp34}$ & -0.423 & -0.578 \\
C. britskii & $\mathrm{sp37}$ & 0.001 & 0.615 \\
Abiotic & & & 0.561 \\
Total nitrogen & $\mathrm{Nt}$ & -0.471 & 0.526 \\
Total phosphorus & $\mathrm{Pt}$ & 0.041 & -0.409 \\
Rain precipitation & $\mathrm{Pluvio}$ & -0.318 & 0.451 \\
pH & $\mathrm{pH}$ & 0.284 & 0.410 \\
Temperature & $\mathrm{T}$ & 0.066 & 0.445 \\
Conductivity & $\mathrm{K}$ & 0.174 & 0.503 \\
Turbidity & $\mathrm{Turb}$ & -0.359 & -0.418 \\
Total suspended solids & $\mathrm{SSt}$ & & \\
\hline
\end{tabular}

striatus (sp13), Hypostomus sp2 (sp30) and Pimelodus maculatus (sp33) were better correlated to the positive side of the axis 1 , associated to lower values of total nitrogen and suspended matter. The species B. stramineus (sp5) and Rhamdia quelen ( $\mathrm{sp} 34$ ) were better positioned on the negative side of axis 1 , associated to high concentrations of total nitrogen and suspended solids.

The species $B$. stramineus (sp5), $R$. descalvadensis (sp18) and Serrasalmus maculatus (sp21) were located on the positive side of the axis 2 , associated to high concentrations of total nitrogen, total phosphorus and suspended solids, as well as to high temperature, turbidity, conductivity and precipitation. The species $R$. quelen (sp34) and $C$. britskii (sp37) were positioned on the negative side of axis 2, associated with higher $\mathrm{pH}$ values.

Some associations between the sampling stations and the ichthyofauna could also be identified through the CCA analysis. Rhamphichthys hahni (sp27) and $S$. marmoratus (sp42) exhibited a high correlation with the FPA in January; Galeocharax knerii (sp7) with FPB in January; Serrasalmus marginatus (sp22) with FPB in March; Cichlasoma paranaense (sp36) with FPB in May; Crenicichla haroldoi (sp38) with the FPC in January; Trachelyopterus galeatus (sp32) with FPC in March; L. striatus (sp13) and Hypostomus sp2 (sp30) with FPC in May; P. maculatus (sp33) with FPD in May and $R$. quelen (sp34) with PR in September.

\section{Discussion}

The role of lateral lagoons as a prominent ecological habitat for small freshwater fish has been widely demonstrated for the Neotropical region (Gafny et al., 2000; Barrella and Petrere Junior, 2003; Casatti et al., 2003; De Lima and Araujo-Lima, 2004; Pelicice and Agostinho, 2005, 2006, 2009). The importance of the lagoon/river connectivity on the composition and the ecological attributes of fish assemblages is also reinforced by the results of the present study.

The fish richness observed in the Rosana Reservoir lagoons during the present study, 42 species, represents $57 \%$ of the total number of species registered in the lower stretch of the Paranapanema River (Britto and Carvalho, 2006; Duke Energy, 2003). Higher richness in the lagoons was an expected result due to the fact that these environments exhibit a wider habitat variety, including food resources, when compared to river channel (Lachavanne and Juge, 1997).

In previous inventories carried out in vegetated (littoral) habitats of Rosana Reservoir, Casatti et al. (2003) found 20 different fish species. The same number was observed by Pelicice et al. (2005), also associated to aquatic vegetation stands in the reservoir. The relatively high number of species found in the present work is probably a consequence of a comparatively higher sampling effort (six periods and five different areas). Casatti et al. (2003) studied only one area (corresponding to our FPB sampling station) during 4 periods and Pelice et al. (2005) studied 2 areas in a single period of the year. In relation to this last study, the relatively low richness can also be associated to the reservoir compartments which were investigated - the central channel and the lacustrine zone near the dam. It should be mentioned that we have not found 4 species which were already registered in the littoral zones of Rosana 
Reservoir: Apareiodon affinis, Loricariichthy labialiis (Casatti et al., 2003), Schizodon borelli and Sternopygus macrurus (Pelicice et al., 2005).

Most species found in the study belong to Characiformes, followed by Siluriformes and Perciformes. The dominance of Characiformes in Neotropical fish assemblages is a recurrent pattern (Lowe-McConnell, 1999; Langeani et al., 2007) and has been confirmed by the Paranapanema River inventories (Britto and Carvalho, 2006; Vianna and Nogueira, 2008).

Characiformes predominated in all sampling stations, but their abundance was even higher in the lagoons with lower connectivity with the river $(r=0.84$; Pearson coefficient). This fact indicates that the lagoons offer better conditions for the surviving of these small-sized species, constituting a preferential residence site as demonstrate by Agostinho et al. (2000). At the river bank (PR), there was a higher proportion of Perciformes, represented by piscivorous fish (except $S$. pappaterra). Probably, as the predation impact on these species is not too intense, they do not need to search for refuge in the lagoons, also being capable of exploiting environments with lower food availability (Novaes et al., 2004).

The correlation analyses based on the fish assemblage composition and abundance showed a higher similarity between the river bank sampling station (PR) and the most connected lagoon (FPC). This analysis also revealed a second group, constituted by the lagoons, in which the fish assemblages from more disconnected lagoons were more distinct then those from the river channel.

The positioning of the lateral lagoons in relation to the reservoir longitudinal main axis seems to have an important role for the fish fauna. The fish abundance observed in FPA was almost twice as high than the values from the other sampling stations. This lagoon is the most upstream located, around $90 \mathrm{~km}$ from the dam, which could be an important factor for the spawning of the migratory species, for instance. Another possibility to explain the high fish abundance in this lagoon is the fact that it is closer to the mouth of two important tributary rivers (Pirapó and Pirapozinho). Conversely, in the FPD, which is the most downstream located ( $80 \mathrm{~km}$ from dam), higher fish biomass was found, despite lower abundance, indicating that this lagoon is a more suitable place for fish growth than the others.

High mean length of the fish observed at the river bank (station PR) could be related to the fact that this reservoir compartment (river channel - open area) is preferentially occupied by older fish stages of small-sized species and young of large sized species.

The correlation between the ichthyofauna and the distinct environmental variables and also a possible spatial segregation among some species was evidenced by the canonical correspondence analysis. Most species were generalist, but some were associated to particular seasonal environmental conditions of each lagoon. These results support the theory that these organisms are sensitive to the changes in the environmental conditions and also corroborate the idea that the ichthyofauna can be used as a good ecological indicator (Gafny et al., 2000; Barrella and Petrere Junior, 2003).

Besides the distinctiveness among the sampling stations, the ichthyofauna, as well as the environmental variables, showed clear differences along the year due to the typical regional alternation between the dry (winter) and rainy (summer) seasons.

During the warm and rainy months, mainly from November to January, the individuals mean length was low and the abundance was high. This result corroborates previously observed regional patterns, where most populations exhibit a marked seasonality in recruitment rates (Baumgartner et al., 2004; Bialetzki et al., 2005).

In all sampling stations there was a strong dominance of few species, especially of $H$. marginatus. The marked dominance by few species was also observed in other rivers and reservoirs from the regions South and Southeast of the country (Carvalho et al., 1998; Castro et al., 2003). This pattern of few dominant species associated to several low abundant ones, even rare, seems to be characteristic of tropical (either humid or seasonally dry-wet climate) communities (Odum, 2004; Benedito-Cecílio and Agostinho, 2008).

At the FPA, FPB and FPD stations, there was the predominance of constant species. At FPC, there was a high contribution of rare species and, at PR, the accessory species were less abundant and the same number was observed for rare and accessory ones. The high number of constant species in the lateral lagoons, except in the most connected one (FPC) and especially in the larger one (FPD) (14 species), demonstrates that these lentic environments are used as residence sites for a significant proportion of the small-sized fish fauna.

The high fish richness and diversity as well as and the prevalence of constant species in the lagoons located inside the State Park of Morro do Diabo area showed the importance of the terrestrial area integrity for the maintenance of the aquatic assemblages (Schiemer et al., 1995; Baumgartner et al., 2004).

The increase of the diversity verified during the rainy period, mainly in January, can be related with the concomitant increase of richness and abundance, mainly for the rare species captured in this period. This confirms the assumption that the rare species join the resident ones in certain periods of the year (Uieda, 1984).

This study is one of the first to register the presence of the introduced (Amazonian) carnivorous Cichla kelberi ("Tucunaré") in Rosana Reservoir (Pelicice and Agostinho, 2009). Its high abundance was seen at the FPA where a high number of fish (small-sized individuals) was captured throughout the study. Another two introduced species were also collected, Oligosarcus pintoi and Gymnotus carapo. They had already been recently registered for the reservoir and also from samplings in littoral habitats (Pelicice et al., 2005). These results demonstrate that the lateral lagoons are suitable places for the establishment of non-native predators. The high prey availability, in addition to the absence of alimentary specialty (Hahn et al., 
1997), influences positively the colonisation process (Novaes et al., 2004).

Among the environmental variables, the pluviometric preciptation significantly increase the contribution of alloctonous sediments, resulting in high turbidity and high concentration of nutrients. Conversely, in the dry period there is a significant increase in transparency, neutral $\mathrm{pH}$ conditions and high concentration of dissolved oxygen. Among the sampling stations, it was verified that the main channel was more variable seasonally, indicating that the lateral lagoons are more conservative (higher stability) systems. A detailed study on the limnology characteristics of the studied environment is presented by Ferrareze et al. (in press).

The results validate the hypotheses that lateral lagoons have a prominent ecological role in the life cycle of juveniles and small fish and demonstrate how the connectivity river/lagoons may be important for these assemblages. The results indicate that the incorporation of marginal lagoons in environmental programs should be a good strategy for the conservation of the aquatic biodiversity, minimising the negative impact of the dam on the rivers ichthyofauna.

Acknowledgements - The authors are grateful to the Coordenação de Aperfeiçoamento de Ensino Superior (CAPES) for the scholarship conceded to the first author; to Dr Francisco Langeani Neto for helping with fish identification; and to Duke Energy International Geração Paranapanema for the financial support.

\section{References}

AGOSTINHO, AA., THOMAZ, SM., BALTAR, SLSMA. and GOMES, LC., 2002. Influence of aquatic macrophytes on fish assemblage structure of Upper Paraná River lateral (Brazil). In Proceedings of the 11th EWRS International Symposium on Aquatic Weeds, 2002. Moliets et Maâ, France. p. 69-72.

AGOSTINHO, AA., THOMAZ, SM., MINTE-VERA, CV., and WINEMILLER, KO., 2000. Biodiversity in the Paraná River Lateral. In GOPAL, B., JUNK WJ. and DAVIS JA. (Eds.). Biodiversity in wetlands: assessment, function and conservation. Leiden: Backhuys Publishers. p. 89-118.

AHEARN DS., SHEIBLEY, RW. and DAHLGREN, RA., 2005. Effects of river regulation on water quality in the Lower Mokelumne River, California. River Research and Applications, vol. 21, p. 651-670. http://dx.doi.org/10.1002/rra.853

BARRELLA, W. and PETRERE JUNIOR, M., 2003. Fish community alterations due to pollution and damming in Tietê and Paranapanema Rivers (Brazil). River Research and Applications, vol. 19, p. 59-76. http://dx.doi.org/10.1002/rra.697

BAUMGARTNER, G., NAKATANI, K., GOMES, LC., BIALETZKI, A., SANCHES PV. and MAKRAKIS, MC., 2004. Identification of spawning sites as natural nurseries in the Upper Paraná River. Environmental Biology of Fish, vol. 71, p. 115-125. http://dx.doi.org/10.1007/s10641-003-0098-z
BEAUMORD, AC. and PETRERE JUNIOR, M., 1994. Comunidades de peces del Rio Manso, Chapada dos Guimarães, MT, Brasil. Acta Biologica De Venezuela, vol. 15, no. 2, p. 21-35.

BENEDITO-CECILIO, E. and AGOSTINHO, AA., 2008. Distribuição, abundância e uso de diferentes ambientes pela ictiofauna dominante na área de influência do reservatório de Itaipu. Acta Scientiarum, vol. 22, no. 2, p. 429-437. Available from: $<$ http://www.periodicos.uem.br/ojs/index.php/ActaSciBiolSci/ article/view/2961/2111>. Access in: 14 jul. 2009.

BIALETZKI, A., NAKATANI, K., GOMES, LC., SANCHES, PV. and BAUMGARTNER, G., 2005. Larval fish assemblage in the Baía River (Mato Grosso do Sul State, Brazil): temporal and spatial patterns. Environmental Biology of Fish, vol. 73, p. 37-47.

BRITTO, SGC. and CARVALHO, ED., 2006. Ecological attributes of fish fauna in the Taquaruçu reservoir, Paranapanema River (upper Paraná, Brazil): composition and spatial distribution. Acta Limnologica Brasiliensia, vol. 18, p. 377-388.

BRITSKI, HA., 1972. Peixes de água doce do Estado de São Paulo. In Comissão Interestadual da Bacia Paraná-Uruguai (Ed.). Poluição e Piscicultura. São Paulo. p. 79-108.

BRITSKI, HA., SATO, Y. and ROSA, ABS., 1986. Manual de identificação de peixes da região de Três Marias (com chaves de identificação para os peixes da bacia do São Francisco). Brasília: Câmara dos Deputados/ CODEVASF. 143 p.

BRITSKI, HA., SILIMON, KZS. and LOPES, SL., 1999. Peixes do Pantanal, manual de identificação. Brasília: EMBRAPA Corumbá. $184 \mathrm{p}$.

CARVALHO, ED., SILVA, VFB., FUJIHARA, CY., HENRY, R. and FORESTI, F., 1998. Diversity of fish species in the River Paranapanema - Jurumirim Reservoir transition region (São Paulo, Brazil). Italian Journal of Zoology, vol. 65, suppl, p. 325-330.

CASATTI, L., MENDES, HF. and FERREIRA, KM., 2003. Aquatic macrophytes as feeding site for small fish in the Rosana Reservoir, Paranapanema River, Southeastern Brazil. Brazilian Journal of Biology, vol. 63, no. 2, p. 1-8. http://dx.doi.org/10.1590/ S1519-69842003000200006

CASTRO, RMC., CASATTI, L., SANTOS, HF., FERREIRA, KM., RIBEIRO, AC., BENINE, RC., DARDIS, GZP., MELO, ALA., STOPIGLIA, R., ABREU, TX., BOCKMANN, FA. , CARVALHO, M., GIBRAN, FZ. and LIMA, FCT., 2003. Estrutura e composição da ictiofauna de riachos do rio Paranapanema, Sudeste e Sul do Brasil. Biota Neotropica, vol. 3, p. 1-34.

COLE, GA., 1979. Textbook of limnology. 2nd ed. Saint Louis: The C.V. Mosby Company. 426 p.

DAJOZ, R., 1973. Ecologia Geral. São Paulo: Vozes Ltda., EDUSP. 474 p.

DE LIMA, AC. and ARAUJO-LIMA, CARM., 2004. The distributions of larval and juvenile fish in Amazonian rivers of different nutrient status. Freshwater Biology, vol. 49, no. 6, p. 787-800. http://dx.doi.org/10.1111/j.1365-2427.2004.01228.x

DUKE ENERGY, 2003. Peixes do rio Paranapanema (métodos de amostragem, as espécies e características). São Paulo: Horizonte Geográfico. 112 p.

FERRAREZE, M., NOGUEIRA, MG. and SARTORI, LP. Limnology of lateral lagoons in a tropical reservoir (SE, Brazil) - spatial and temporal variability. Limnetica, in press. 
GAFNY, S., GOREN M. and GASITH, A., 2000. Habitat condition and fish assemblage structure in a coastal Mediterranean stream (Yarquon, Israel) receiving domestic effluent. Hydrobiologia, vol. 422-423, p. 319-330. http://dx.doi.org/10.1023/A:1017040017238

GRAÇA, WJ. and PAVANELLI, CS., 2007. Peixes da planície de inundação do alto rio Paraná e áreas adjacentes. Maringá: EDUEM. $241 \mathrm{p}$.

HAHN, NS., ANDRIAN, IF., FUGI, R. and ALMEIDA, VLL., 1997. Ecologia trófica. In VAZZOLER, AEAM., AGOSTINHO, AA. and NORMA, SH. (Eds.). A planície de inundação do alto Paraná: Aspectos físicos, biológicos e socioeconômicos. Maringá: GT GRAF. p. 209-228.

HENRY, R., 2005. The connectivity of the Paranapanema River with two lateral lakes in its mouth zone into the Jurumirim Reservoir. Acta Limnologica Brasiliensia, vol. 17, no. 1, p. 57-69.

KENNEDY RH., TUNDISI, JG., STRASKRABA, V., LIND, OT. and HEJZLAR, J., 2003. Reservoirs and the limnologist's growing role in sustainable water resource management. Hydrobiologia, vol. 504, p. xi-xii.

KREBS C.J., 1989. Ecological methodology. New York: Harper Collins. 624 p.

LANGEANI, F., CASTRO, RMC., OYAKAWA, OT., SHIBATTA, OA., PAVANELLI, CS. and CASATTI, L., 2007. Ichthyofauna Diversity Of The Upper Rio Paraná: Present Composition and future perspectives. Biota Neotropica, vol. 7, no. 3, p. 181-197. http://dx.doi.org/10.1590/S1676-06032007000300020

LACHAVANNE, JB. and JUGE, R., 1997. Biodiversity in Land/ Inland Water Ecotones (Man and the Biosphere Series). Informa HealthCare. 326 p.

LOWE-MC CONNELL, RH., 1999. Estudos ecológicos de comunidades de peixes tropicais. VAZZOLER, AEAM., AGOSTINHO, AA. and CUNNINGHAM, PTM. (Trad.). São Paulo: EdUSP. 535 p.

MACKRETH, FJH., HERON, J. and TALLING, FJ., 1978. Water analysis: some revised methods for limnologists. Kendall: Freshwater Biological Association,Titus Wilson and Sons Ltd. 120 p. Scientific Publication, no. 36.

MAGURRAN, AE., 2004. Measuring Biological Diversity. London: Blackwell Publishing. 256 p.

McCUNE, B. and MEFFORD, MJ., 1999. PC-ORD for windows: multivariate analysis of ecological data. Version 4.1. Oregon: MjM Software Design.

MESCHIATTI, AJ., ARCIFA, MS. and FENERICH-VERANI, N., 2000. Fish communities associated with macrophytes in Brazilian lateral lakes. Environmental Biology of Fish, vol. 58, no. 2, p. 133-143.

NALIATO, DAO., NOGUEIRA, MG. and PERBICHE-NEVES, G., 2009. Discharge pulses of hydroelectric dams and their effects in the downstream limnological conditions: a case study in a large tropical river (SE Brazil). Lakes and Reservoirs, vol. 14, p. 301-314. http://dx.doi.org/10.1111/j.1440-1770.2009.00414.x

NELSON, JS., 2006. Fish of the World. 4nd ed. New York: John Wiley and Sons. p. 141-175.

NOGUEIRA, MG., JORCIN, A., VIANNA, NC. and BRITTO, YCT., 2006. Reservatórios em cascata e os efeitos na limnologia e organização das comunidades bióticas (fitoplâncton, zooplâncton e zoobentos) - um estudo de caso no rio Paranapanema. In NOGUEIRA, MG., HENRY, R. and JORCIN, A. (Eds.). Ecologias de reservatórios: impactos potenciais, ações de manejo e sistema em cascata. São Carlos: Rima. p. 83-125. cap. 4.

NOVAES, JLC., CARAMASCHI, EP. and WINEMILLER, KO., 2004. Feeding of Cichla monoculus Spix, 1829 (Teleostei, Cichlidae) during and after reservoir formation in the Tocantins River, central Brazil. Acta Limnologica Brasiliensia, vol. 16, no. 1, p. 41-49.

ODUM, EP., 2004. Fundamentals of Ecology. 5nd ed. Brooks Cole. $624 \mathrm{p}$.

PELICICE, FM. and AGOSTINHO, AA., 2006. Feeding ecology of fish associated with Egeria spp. patches in a tropical reservoir, Brazil. Ecology of Freshwater Fish, vol. 15, p. 10-19. http://dx.doi. org/10.1111/j.1600-0633.2005.00121.x

-, 2008. Fish-passage facilities as ecological traps in large Neotropical Rivers. Conservation Biology, vol. 22, p. 180-188. http://dx.doi.org/10.1111/j.1523-1739.2007.00849.x

-, 2009. Fish fauna destruction after the introduction of a non-native predator (Cichla kelberi) in a Neotropical Reservoir. Biological Invasions, vol. 11, p. 1789-1801. http://dx.doi.org/10.1007/ s10530-008-9358-3

PELICICE, FM., AGOSTINHO, AA. and THOMAZ, SM., 2005. Fish assemblages associated with Egeria in a tropical reservoir: investigating the effects of plant biomass and diel period. Acta Oecologica, vol. 27, p. 9-16. http://dx.doi.org/10.1016/j. actao.2004.08.004

PIECZYNSKA, E., 1995. Habitas e comunidades litorâneas. In JORGENSEN, SE. and LOFFER, H. (Eds.). Diretrizes para o gerenciamento de lagos: gerenciamento de litorais lacustres. Shiga: Itagura-kabo Co., Ltda. Otsu. p. 40-76.

REIS, RE., KULLANDER, SO. and FERRARIS JUNIOR, CJ., 2003. Check list $f$ the freshwater fish of South and Central America. Porto Alegre: EDIPUCRS. 742 p.

ROZAS, LP. and ODUM, WE., 1988. Occupation of submerged aquatic vegetation by fish: testing the roles of food and refuge. Oecologia, vol. 77, p. 101-106. http://dx.doi.org/10.1007/ BF00380932

SCHIEMER, F., ZALEWISK, M. and THORPE, J., 1995. Land/ inland water ecotones: Intermediate habitats critical for conservation and management. Hydrobiologia, vol. 303, no. 1-3, p. 259-264. http://dx.doi.org/10.1007/BF00034063

SCHRIVER P., BOGESTRAND, J., JEPPESEN, E. and SONDERGAARD, M., 1995. Impact of submerge macrophytes on fish-zooplankton-phytoplankton interactions: large scale enclosure experiments in a shallow eutrophic lake. Freshwater Biology, vol. 33, p. 255-270. http://dx.doi.org/10.1111/j.1365-2427.1995. tb01166.x

SOARES MCS., MARINHO, MM., HUSZAR, VLM., BRANCO, CWC. and AZEVEDO, SMFO., 2008. The effects of water retention time and watershed features on the limnology of two tropical reservoirs in Brazil. Lakes and Reservoirs Research Management, vol. 13, p. 257-269. http://dx.doi.org/10.1111/j.14401770.2008.00379.x 
SOKAL, RR. and ROHLF, FJ., 1979. Biometría: Principios y métodos estadísticos en la investigación biológica. Madrid: Blume. 832 p.

Statsoft, 2001. Statistica (data analysis software system). Version 6. Tulsa: Statsoft, Inc.

STRICKLAND, JD. and PARSONS, TR., 1960. A manual of sea water analysis. Bulletin of Fisheries Board of Canada, vol. 125 , p. $1-185$.

TUNDISI JG. and MATSUMURA-TUNDISI, T., 2003. Integration of research and management in optimizing multiple uses of reservoirs: the experience in South America and Brazilian case studies. Hydrobiologia, vol. 500, p. 231-242. http://dx.doi. org/10.1023/A:1024617102056
UIEDA, VS., 1984. Ocorrência e distribuição dos peixes de um riacho de água doce. Brazilian Journal of Biology, vol. 44, no. 2, p. 203-213.

UNDERWOOD, AJ., 1997. Experiments in Ecology: Their Logical Design and Interpretation Using Analysis of Variance. London: Cambridge University Press. 432 p.

VALDERRAMA, JG., 1981. The simultaneous analysis of total nitrogen and phosphorus in natural waters. Marine Chemistry, vol. 10, p. 109-122. http://dx.doi.org/10.1016/0304-4203(81)90027-X

VIANNA, NC. and NOGUEIRA, MG., 2008. Ichthyoplankton and limnological factors in the Cinzas River an alternative spawning site for fish in the middle Paranapanema River basin (Brazil). Acta Limnologica Brasiliensia, vol. 20, p. 117-130. 